\title{
大口蓋神経由来と思われた巨大な神経鞘腫の一例
}

\author{
北野尚孝・深澤壽法・中村佳世子 \\ 吉田美昭・植木輝一

\section{A case of a huge neurilemoma considered to arise from the greater palatine nerve} \\ KITANO Hisataka · FUKAZAWA Toshimichi · NAKAMURA Kayoko \\ YOSHIDA Minori · UEKI Terukazu

\begin{abstract}
Neurilemoma is an uncommon benign tumor of the oral and maxillofacial region. We report a huge neurilemoma, measuring $40 \times 35 \mathrm{~mm}$, in the palate of a 22 -year-old man. The lesion was surgically excised with the patient under general anesthesia. The tumor was confirmed to communicate with the greater palatine nerve at surgery. Histopathologically, it was diagnosed as a neurilemoma, Antoni A and B type. There has been no recurrence during postoperative follow-up of 36 months.
\end{abstract}

Key words: neurilemoma（神経鞘腫）, greater palatine nerve（大口蓋神経), huge（巨大）

緒言

神経鞘腫は神経鞘の schwann 細胞や神経周膜の線維芽 細胞に由来すると考えられる良性腫瘍で，その多くは四肢 または頭頸部の皮下に発生する．特に頭頸部においては, 煩部および側頭窩下に多く発生し，口腔領域で生じること は比較的まれであり全体の $0.02 \%$ と報告されている ${ }^{1,2)}$. また，口腔領域では多くが舌に発生し，まれに煩粘膜，口 底，柬肉抢よび口蓋に生じると報告されている ${ }^{3,4)}$. 今回， われわれは大口蓋神経由来と考えられる巨大な神経鞘腫の 一例を経験したのでその概要を報告する.

\section{症例}

患 者： 22 歳, 男性.

初診：2003 年 10 月 15 日.

主 訴：硬口蓋の腫瘤.

既往歴および家族歴：特記事項なし.

現病歴：10 年前より硬口蓋に腫瘤の存在を自覚してい たが放置していた．2003 年 10 月初旬，近菊科を受診した

日本大学医学部菌科口腔外科学教室

(主任：植木輝一助教授)

Department of Oral and Maxillofacial Surgery, School of Medicine, Nihon University (Chief: Associate Prof. UEKI Terukazu)

受付日：2007年 1 月 19 日

採択日：2007 年 12 月 25 日
際，硬口蓋の腫瘤を指摘され精查目的にて当科を紹介受診 した。

口腔外所見：体格は中等度，栄養状態は良好で全身的に 異常は認めなかった。

口腔内所見 : 左側硬口蓋にわたる右側硬口蓋を起始部と した $40 \times 35 \mathrm{~mm}$ の広基性で表面不規則な弾性硬の腫瘤が 存在した。また腫瘤の一部に潰瘍形成を認め軽度の構音障 害を伴っていた（写真 1).

MRI 所見：MRI 検査では右側小眠菊部硬口蓋から軟口 蓋にかけて境界明瞭な腫瘤を認めた。病宩は $\mathrm{T} 1$ 強調像で 筋肉と等信号を，T2 強調像で筋肉より淡い高信号を示し た。また，Gd-DTPAにおいて病巣部に造影効果を認めた (写真 2).

処置および経過：初診時に腫瘍の試験切除を施行し病理 組織学的検査を行った結果，神経鞘腫と診断された。 2003 年 11 月 27 日全身麻酔下にて腫瘍切除術を施行した（写真 3). 切除時, 上顎骨は温存し腫瘍は骨膜を含め切除した. その際肉眼的に腫瘍と大口蓋神経血管束との連続性が認め られたため，大口蓋神経血管束を結紮し切断した。また， 上顎骨の骨吸収や基質的変化は認められなかったため, 上 顎骨に対する処置は行わなかった．腫瘍切除後の粘膜欠損 部に人工コラーゲン膜を貼付し, 口蓋床にて創部を保護し た. 術直後, 右側大口蓋神経支配領域の知覚欠如を認めた. また初診時より認めていた構音障害は消失した. 以後 3 年 


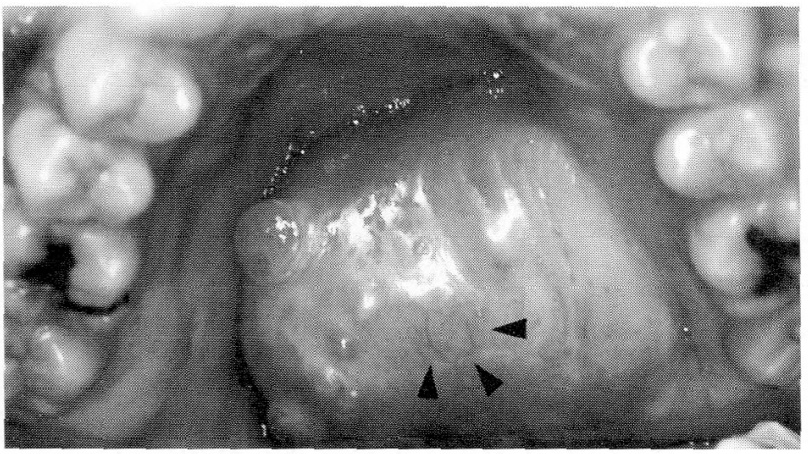

写真 1 初骖時17腔内写真

右側硬口蓋から左側硬口蓋にかけて $40 \times 35 \mathrm{~mm}$ の広 基性で弾性硬の腫瘤を認めた。また腫瘤の一部に潰瘍を 認めた (矢印).
以上経過した現在，右側大口盍神経支配領域の知覚欠如を 認めるも構音障害および再発傾向はなく経過良好である。

摘出標本所見：摘出標本は $40 \times 35 \times 18 \mathrm{~mm}$ で, 表面走 薄い線維性皮膜で覆わ机た腫瘍であった（写真 4).

病理組織学的所見：口蓋粘膜下に周囲を線維性被膜で囲 まれた腫痬が認められた。また，腫瘍細胞は紡鍾形ないし 楕円形の核を有する双極性の細長い細胞が束状扎よび渦巻 状構造を呈し，血構造な基質をはさんで榜が規則正しく並 ぶ椢状配列いわゆる観兵様配列が認められた。また粘膜腫 様間質のなかに腫瘍細胞が粗に配列し，細線維がそしく不 規則な走向をする部分も認められ典型的な Antoni A 型と Antoni B 型の混在型であった(写真 5).

天状断

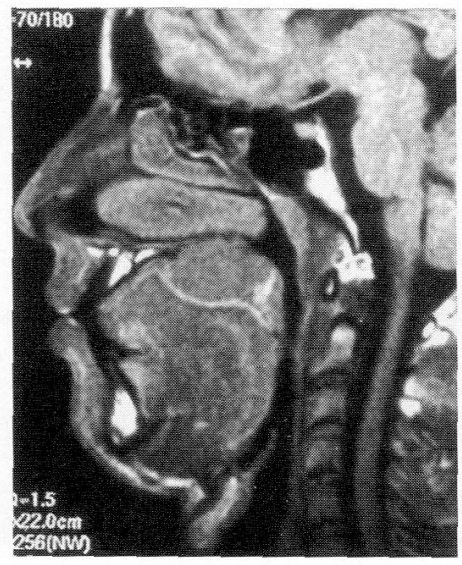

T1 強調像

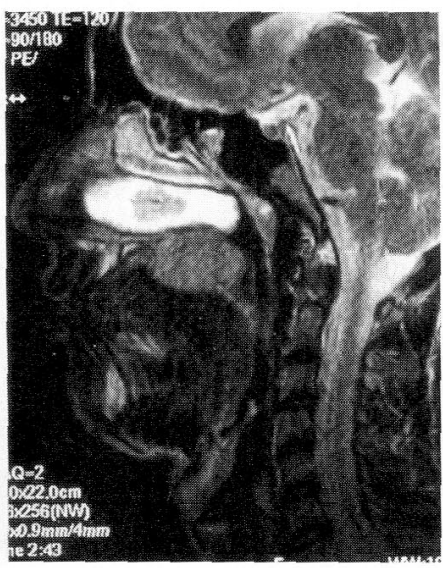

T2 強調像

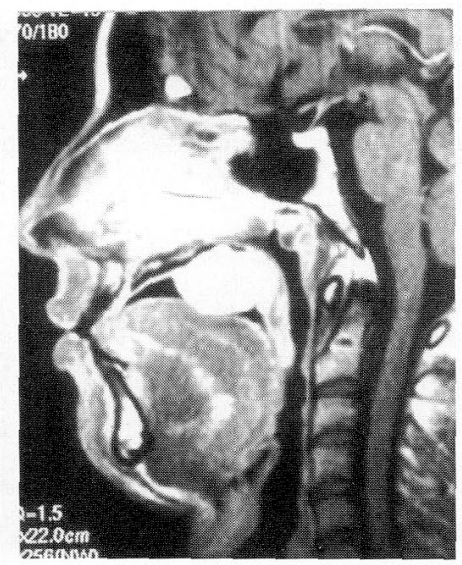

Gd-DTPA

水平断

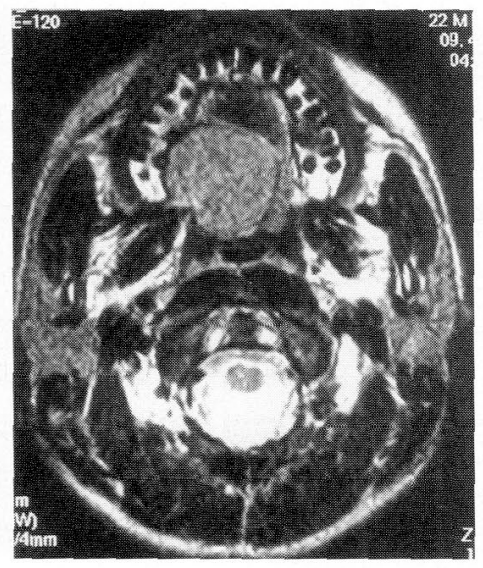

$\mathrm{T} 2$ 強調像

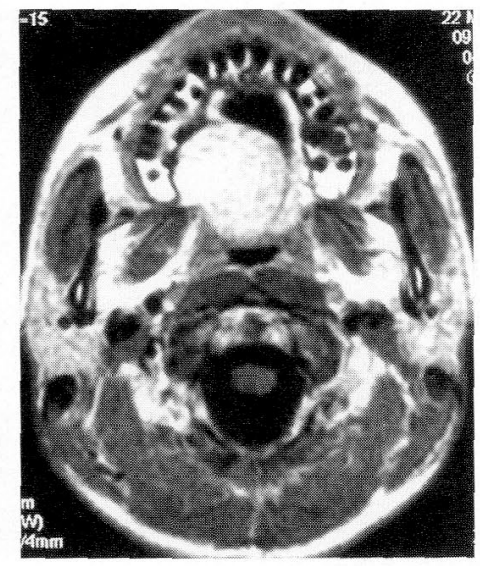

Gd-DTPA

写真 2 初診時 MRI 像

T1 : TR ; 590, TE； 15 T2 : TR ; 3450, TE ; 120 Gd-DTPA：TR； 590, TE ; 15

MRI 造影検査では両側小臼㐘部硬口蓋から軟口蓋にかけて境界明瞭な腫瘤を認めた。また内部に不均一な造影効果を認めた. 


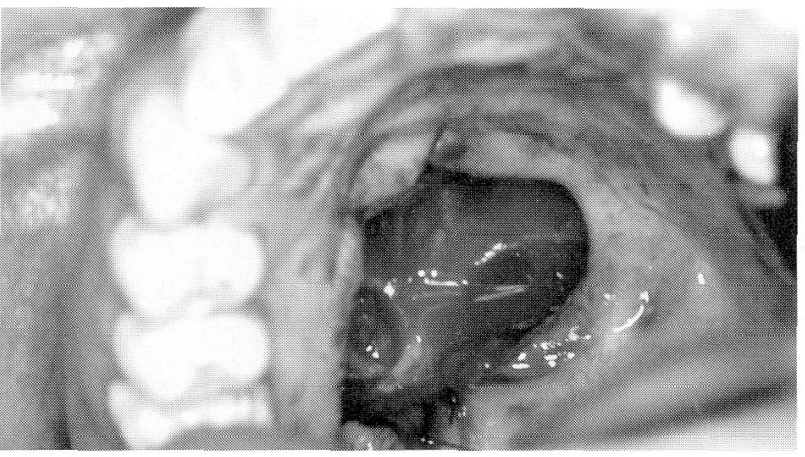

写真 3 術中写真

硬口盍に骨の陷没を認め，肉眼的に腫瘍と大口蓋神経 血管束との連続性が認められた。

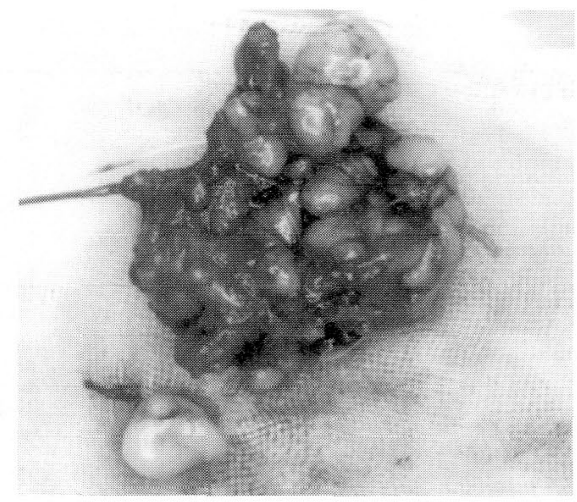

写真 4 摘出標本写真

摘出標本は数個の小塊から成っており，黄白色を呈し て抢り弾性硬であった。摘出標本の上方は被膜がはがさ れ腫瘍実質が明示されており，下方は線維性被膜で覆わ れている.
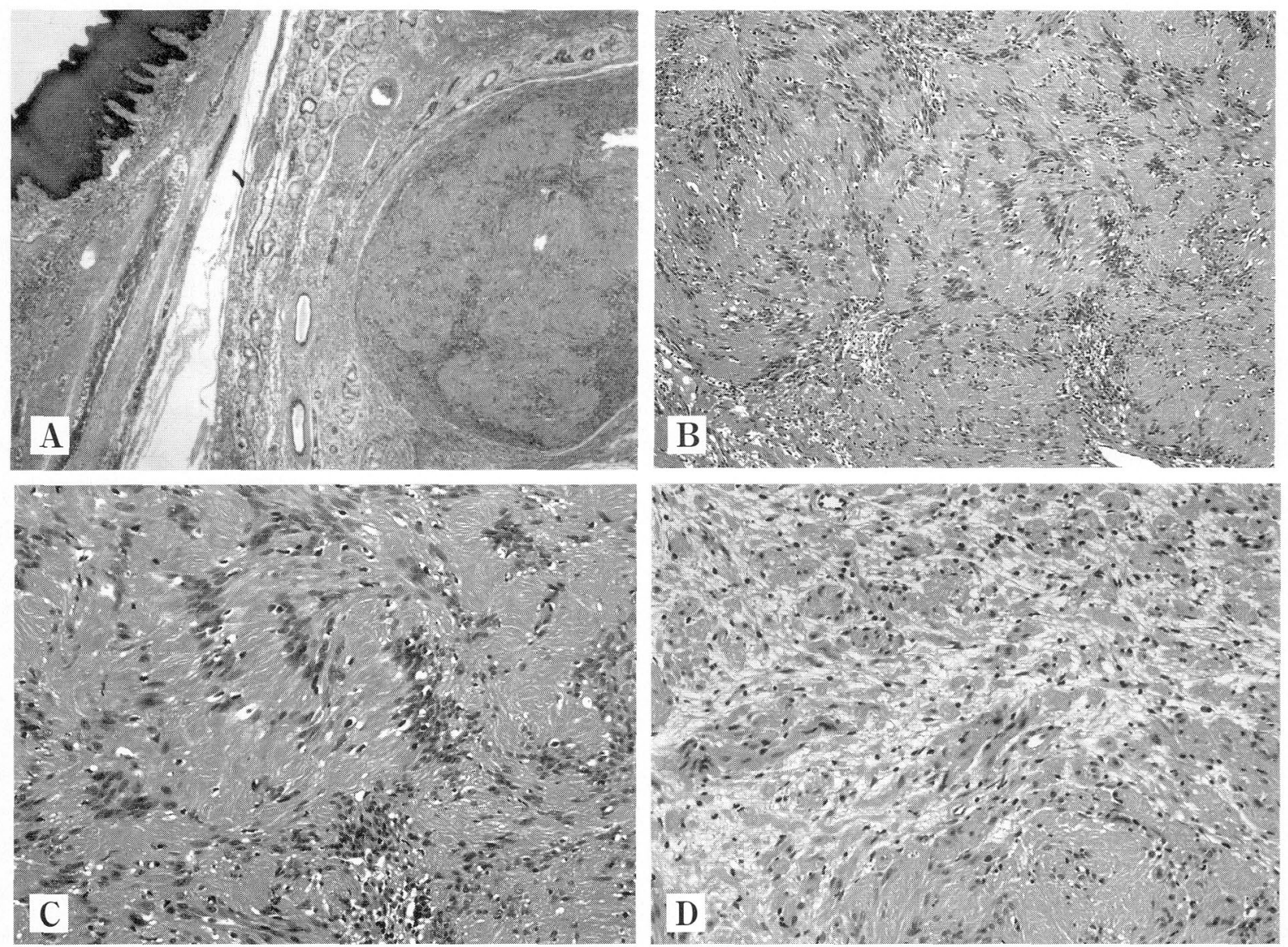

写真 5 病理組織像（H-E 染色）

A : 弱桩大

口蓋粘膜下に境界明腺な充実性結節性腫瘍が認められた。

$\mathrm{B}$ ：中拡大, $\mathrm{C}$ : 強拡大 (Antoni A 型), D : 強拡大 (Antoni B 型)

紡鍾形ないし楕円形の核を有する細胞が束状に増生し，核が規則正しく並ぶ観兵様配列を呈する Antoni A 型の 部分が大半を占めていたが，一部に粘液腫様間質を示す Antoni B 型の像が認められた。 
表 1 本邦に打ける口蓋に発生した神経鞘腫の報告例

\begin{tabular}{|c|c|c|c|c|c|c|c|}
\hline 症例 No. & 発 表 者 & 発表年 & 年齢 & 性別 & 大きさ $(\mathrm{mm})$ & 発生部位 & Antoni 分類 \\
\hline 1 & 井出 守義 5) & 1941 & 51 & 男 & 不明 & 軟口蓋 & 不明 \\
\hline 2 & 奥田儀一郎 6) & 1957 & 36 & 女 & $50 \times 35 \times 27$ & 軟口蓋 & 不明 \\
\hline 3 & 小出 隆康 & 1962 & 22 & 女 & $15 \times 7$ & 硬口蓋 & A型 \\
\hline 4 & 福間 公介7) & 1962 & 29 & 女 & $15 \times 20 \times 5$ & 硬口蓋 & 不明 \\
\hline 5 & 松丸 秀明 & 1964 & 24 & 男 & $35 \times 25 \times 20$ & 軟口蓋 & A型 \\
\hline 6 & 石井 英夫 ${ }^{8)}$ & 1968 & 19 & 女 & $20 \times 15 \times 15$ & 軟口蓋 & A型 \\
\hline 7 & 滝川＼cjkstart富雄9） & 1970 & 4 & 男 & 拇指頭大 & 硬口盍 & A型 \\
\hline 8 & 登 10) & 1976 & 20 & 女 & 小指頭大 & 硬口蓋 & A型 \\
\hline 9 & 阿部 節子 & 1976 & 15 & 女 & $20 \times 26$ & 硬口蓋 & A型 \\
\hline 10 & 宮 和貴夫 & 1981 & 27 & 男 & $15 \times 10 \times 10$ & 軟口蓋 & A型 \\
\hline 11 & 小河原利影 & 1982 & 79 & 女 & 不明 & 硬口盍 & $\mathrm{A} \cdot \mathrm{B}$ 混在型 \\
\hline 12 & 山下 尚之11) & 1985 & 19 & 女 & $20 \times 15 \times 10$ & 軟口蓋 & A型 \\
\hline 13 & 高野 信夫 & 1986 & 24 & 女 & $20 \times 20 \times 20$ & 硬口蓋 & A型 \\
\hline 14 & 和田 好弘 & 1986 & 50 & 男 & 不明 & 硬口蓋 & 不明 \\
\hline 15 & 若松＼cjkstart常信 12) & 1986 & 12 & 男 & $40 \times 30 \times 25$ & 硬口蓋 & A型 \\
\hline 16 & 晃 13$)$ & 1987 & 12 & 男 & $5 \times 8$ & 硬口蓋 & A·B混在型 \\
\hline 17 & 長野 紀也 & 1987 & 12 & 女 & $24 \times 28$ & 硬口蓋 & A型 \\
\hline 18 & 亀山＼cjkstart嘉光 ${ }^{14)}$ & 1988 & 13 & 男 & $15 \times 10$ & 軟口蓋 & A型 \\
\hline 19 & 喜多＼cjkstart孝志 15) & 1988 & 73 & 女 & $35 \times 30 \times 30$ & 軟口蓋 & 不明 \\
\hline 20 & 大森＼cjkstart昭輝 16) & 1989 & 51 & 女 & 不明 & 硬口蓋 & 不明 \\
\hline 21 & 佐々木 勲 17) & 1989 & 25 & 女 & $25 \times 23 \times 16$ & 硬口蓋 & A型 \\
\hline 22 & 村岡 斉 & 1990 & 19 & 女 & $27 \times 18$ & 硬口蓋 & $\mathrm{A} \cdot \mathrm{B}$ 混在型 \\
\hline 23 & 上園＼cjkstart善子 18) & 1990 & 16 & 男 & $23 \times 30 \times 7$ & 硬口蓋 & $\mathrm{A} \cdot \mathrm{B}$ 混在型 \\
\hline 24 & 伊藤 千鶴 & 1992 & 15 & 男 & 不明 & 硬口蓋 & $A \cdot B$ 混在型 \\
\hline 25 & 浩幸 & 1993 & 12 & 男 & $7 \times 6 \times 2$ & 硬 · 軟口蓋 & A型 \\
\hline 26 & 中村 康典 & 1995 & 55 & 女 & $30 \times 20$ & 口 蓋 & 不明 \\
\hline 27 & 山田＼cjkstart容三19) & 1995 & 21 & 女 & $10 \times 4.5 \times 3.5$ & 硬口蓋 & A型 \\
\hline 28 & 久我むつみ & 1996 & 51 & 男 & $25 \times 20 \times 18$ & 軟口蓋 & $\mathrm{A} \cdot \mathrm{B}$ 混在型 \\
\hline 29 & 中尾 治郎 & 1996 & 26 & 男 & 拇指頭大 & 硬 · 軟口蓋 & A型 \\
\hline 30 & 植田 直人 & 1997 & 53 & 女 & $20 \times 12 \times 14$ & 硬口蓋 & A型 \\
\hline 31 & 若江 秀敏 & 1997 & 44 & 男 & 不明 & 口 蓋 & 不明 \\
\hline 32 & 岸田 & 1998 & 66 & 女 & $15 \times 10 \times 10$ & 口蓋部菊肉 & A型 \\
\hline 33 & 露木＼cjkstart基勝 20) & 1998 & 20 & 女 & $20 \times 15$ & 軟口蓋 & A · B混在型 \\
\hline 34 & 樋口 義高 & 1998 & 14 & 男 & 直径20 & 硬口蓋 & A · B混在型 \\
\hline 35 & 児玉 泰光 & 1999 & 49 & 女 & $17 \times 14 \times 7$ & 硬口蓋 & 不明 \\
\hline 36 & 香取 幸夫 21) & 1999 & 35 & 男 & $15 \times 15 \times 15$ & 軟口蓋 & 不明 \\
\hline 37 & 田口 雄一 & 1999 & 45 & 女 & $10 \times 12$ & 硬口蓋 & A型 \\
\hline 38 & 水野健太郎 & 2000 & 30 & 男 & $14 \times 12$ & 硬口蓋 & A型 \\
\hline 39 & - 22) & 2000 & 23 & 女 & $25 \times 25 \times 30$ & 軟口蓋 & A型 \\
\hline 40 & 岸本 & 2004 & 11 & 女 & $23 \times 20 \times 25$ & 軟口蓋 & 不明 \\
\hline 41 & 本症例 & 2007 & 22 & 男 & $40 \times 35 \times 18$ & 硬口蓋 & A · B混在型 \\
\hline
\end{tabular}

発生年齢は 4 歳から 79 歳で 平均年齢が 30.3 歳であった。 好発年齢において佐々木ら ${ }^{17)}$ の報告によると， 10 歳代～ 20 歳代で平均 25.6 歳と報告して いる. 自験例は 22 歳であり報 告とほぼ類似していた。また 性別においては男女比に明ら かな性差は認めないとしてい るが，われわれの検討におい ては男性 18 例 $(43.9 \%)$ ，女 性 23 例 $(56.1 \%)$ と若干女 性に多く発生する傾向が認め られた。さらに腫瘍の大きさ に打いては, $10 〜 30 \mathrm{~mm}$ 大の ものが圧倒的に多く $40 \mathrm{~mm}$ を 超える腫瘍はわずかに 3 例 (7.3\%) であった。本腫瘍の 大きさは山崎ら ${ }^{23)}$ によると, 腫瘍の発生部位により大きさ が異なり顎下部や口底部に発 生する腫瘍は大きく，その他 の部位では $20 \sim 30 \mathrm{~mm}$ 前後 であると報告されている。今 回の検討に打いても山崎ら ${ }^{23)}$ の報告に類似していたが，自 験例の摘出検体は $40 \times 35 \times$ $18 \mathrm{~mm}$ と口蓋に発生した神経 鞘腫のなかでは極めて大きな 腫瘍であった。これは学童期 より口蓋部の膨隆を自覚して いたがその時点から 10 数年 放置していたことが第一の原 因として考えられた。その結 果，口蓋に発生した神経鞘腫 においては極めて大きな腫瘍 に発育したものと思われた。 また初診時，腫瘍表面に潰瘍 形成をきたしていたのは食事 時の食塊の接触や曣下の際に舌が腫瘍に触れ䀣下圧が加わ り腫瘍表面が自壞し潰瘍形成をおこしたのではないかと考 えられた。ささらに発音する際に舌が腫瘍に触れることによ り粘膜の脱落をおこしたのではないかとも考えられた。ま た発生部位の検討では，硬口蓋に 23 例 $(56.1 \%)$ ，軟口蓋 に 13 例 $(31.7 \%)$ みられ，硬口蓋にやや多く発生していた。

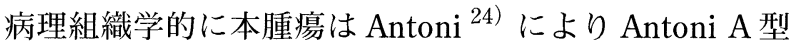


(束状型) および B 型（網状型）に分類されており，今回 われわれが渉猟した症例においても不明なものを除くと， 口蓋に発生した神経鞘腫においては Antoni A 型が 21 例 (70.0\%), Antoni A 型および B 型の混在型が 9 例 $(30.0 \%)$ でAntoni B 型の報告は 1 例もなかった。顎顔面領域に発生 した神経鞘腫において，Antoni A 型が 78/128 例 (61\%)， Antoni B 型が 6/128 例 (5\%)，Antoni A 型および B 型の 混在型が 44/128 例（34\%）であったという黒川ら ${ }^{25 ） の ~}$ 報告がある。また，Moualli ら ${ }^{26)}$ は脊髄神経領域いおいて Antoni B 型の神経鞘腫を報告している．したがって，口蓋 領域において Antoni B 型の神経鞘腫はないか，あっても非 常にまれであり，そのことは口蓋に発生する神経鞘腫の臨 床統計学的な特徴ではないかと考えられた。

神経鞘腫の根治的治療は外科的手術による腫瘍切除が行 われ，術後の神経脱落症状が問題になることが多々認めら れる。本症例では腫瘍が大口蓋神経と肉眼的に癒着してお り術後の右側口蓋部知覚異常が認められた。 また術後に機 能障害が残る可能性のある組織と癒着がある場合はその一 部を残存することもやむをえないとされているが，腫瘍の 再発の可能性はかなり高くなるものと考えられる．また本 腫瘍が再発し悪性化したとの Kun ら ${ }^{27)}$ の報告もあること より，十分な経過観察が必要である.

\section{結語}

今回われわれは硬口蓋に発生した大口蓋神経由来と考え られる巨大な神経鞘腫の一例を経験したので報告した.

本論文の要旨は第 50 回日本口腔外科学会総会 (平成 17 年 10 月，大阪）に打いて発表した。

\section{引 用 文 献}

1）宮崎 正：口腔外科学．松矢篤三，白砂兼光；第 2 版, 医柬薬出版, 東京, 258 頁 2000 .

2) Rossi, G.B. and De Sanctis, A.: Sui Neurilemmomi del cavo orale. Riv Anat Pat Oncol 22: 1047-1071 1961.

3）石井純一，神谷貴充，他：口腔顎顔面領域の神経鞘 腫. 日口外誌 47: 89-92 2001.

4）江口友美，竹田宗弘，他：下歯槽神経に近接し神経 症状がなく経過した下顎骨中心性神経鞘腫の 1 例. 日口外誌 49: 397-400 2003.

5）井出守義：軟口蓋二発生セル「ノイリノーム」ノ一 例. 大日耳鼻会報 47: 745-747 1941 .
6）奥田儀一郎：軟口蓋に発現せるノイリノームの 1 症 例. 耳喉 29: 929-931 1957.

7）福間公介, 野々村徹也, 他：硬口蓋に発生した Neurinomaの 1例. 口科誌 11: 196-199 1962.

8) 石井英夫, 川端五十鈴, 他：神経鞘腫 (Neurilemoma) の電子顕微鏡像について，耳鼻臨 床 61: 231-242 1968.

9）滝川富雄，阿部正彦，他：小児の口蓋に生じた神経 鞘腫の 1 例. 日大菌学 44: 9-14 1970.

10）松田 登, 四方一泉, 他：神経鞘腫の症例とその電 顕所見について. 口科誌 25: 445-450 1976.

11）山下尚之, 龟山忠光，他：軟口蓋にみられた神経鞘 腫の 1 例. 日口外誌 31: 2467-2470 1985.

12）若松常信, 向井洋, 他：上䋶に発生した Schwannomaの 1例. 日口外誌 32: 479-482 1986.

13）北村 晃, 井口次夫, 他：硬口蓋に見られた神経鞘 腫の 1 例. 日口外誌 33: 428-431 1987.

14）亀山嘉光，榊 祥宏，他：軟口蓋に発生した神経鞘 腫の 1 例. 日口外誌 34: 1994-1999 1988.

15）喜多孝志，佐藤 圭, 他：軟口蓋, 咽頭に発現した 巨大な神経鞘腫の 1 例. 口科誌 37: 345-350 1988 .

16）大森昭輝, 武宜, 他：口蓋部にみられた転移性 悪性神経鞘腫の一例. 口腔腫瘍 1: 111-112 1989.

17）佐々木 勲, 佐々木 朗, 他：口蓋に発生した神経 鞘腫の 1 例. 日口外誌 35: 1611-1616 1989.

18）上園善子, 埜口五十雄, 他：口蓋に発生した神経鞘 腫の 1 例（抄). 日口外誌 36: 1118-1119 1990.

19）山田容三，工藤泰一，他：硬口蓋に発生した神経鞘 腫の 1 例. 東医大誌 53: 250-252 1995.

20）露木基勝，山本一彦，他：軟口蓋に発生した神経鞘 腫の 1 例. 日口診誌 11: 123-127 1998.

21）香取幸夫，菊池俊彦，他：軟口蓋に発生した神経鞘 腫の 1 例. 耳喉頭頸 71: 406-407 1999.

22）全一，村上匡孝，他：軟口蓋神経鞘腫例.耳鼻 臨床 93: 383-388 2000.

23）山崎 正，武田 進，他：顎口腔領域に発生した神 経鞘腫 5 例. 日口外誌 27: 968-976 1981.

24) Antoni, N.R.E.: Uber Ruckenmarks Tumoren und Nerofibrome. Munchen, Verlag von J.F. Bergmann 1920.

25）黒川英雄, 津留昭二, 他：神経鞘腫の 5 例. 日口外 誌 36: 1764-1775 1990.

26) Moualli, B.S., Hajri, M., et al.: Retroperitoneal schwannoma. Case report. Int J Surg Pathol 35: 2702722001.

27) Kun, Z., Dao-Yi, Q., et al.: A comparision between the clinical behavior of neurilemomas in the neck and oral and maxillofacial region. J Oral Maxillofac Surg 51: 769-771 1993. 